\title{
Ekstrak Ethanol Daun Sirsak (Annona Muricata) Berpotensi Memiliki Efek Kemoterapi pada Kanker Payudara Tikus Putih
}

\section{Ethanol Extract of Soursop Leaves (Annona muricata) has Potential of Chemotherapy Effect on White Rats' Breast Cancer}

\author{
Muhartono ${ }^{1}$, Indri Windarti ${ }^{1}$, Hendri Busman ${ }^{2}$, Hendra Tarigan $S^{3}$, Bayu Putra DJ $J^{4}$ \\ ${ }^{1}$ Bagian Patologi Anatomi Fakultas Kedokteran Universitas Lampung Bandar Lampung \\ ${ }^{2}$ Laboratorium Biomedik Fakultas Kedokteran Universitas Lampung Bandar Lampung \\ ${ }^{3}$ Bagian Kulit dan Kelamin Fakultas Kedokteran Universitas Lampung Bandar Lampung \\ ${ }^{4}$ Laboratorium Patologi Anatomi Fakultas Kedokteran Universitas Lampung Bandar Lampung
}

\begin{abstract}
ABSTRAK
Kanker payudara merupakan jenis kanker yang terbanyak di derita wanita dan memerlukan kemoterapi berbiaya tinggi dengan efek samping yang banyak. Daun sirsak (Annona muricata) mengandung senyawa asetogenin bersifat sitotoksik terhadap sel kanker. Penelitian ini bertujuan untuk mengetahui efek kemoterapi daun sirsak pada kanker payudara tikus. Penelitian ini merupakan penelitian eksperimental yang dilakukan di Laboratorium Patologi Anatomi FK Unila pada bulan Mei-September 2013 dengan menggunakan 25 ekor tikus betina Sprague Dawley yang dibagi dalam 5 kelompok, yaitu Kelompok I, kontrol negatif; kelompok II, diberikan 75mg/kg BB DMBA, kelompok III diberikan 75mg/kg BB DMBA+ekstrak daun sirsak 100mg/kgBB, kelompok III, 75mg/kg BB DMBA + ekstrak daun sirsak 200mg/kgBB, 75mg/kg BB DMBA+ekstrak daun sirsak III 400mg/kgBB. Ekstrak daun sirsak diberikan selama 4 minggu. Dilakukan pemeriksaan histopatologi untuk menilai apoptosis yang terjadi setelah pemberian daun sirsak. Hasil dianalisis menggunakan uji Kruskall Wallis dan uji Man Whitney. Pemberian ekstrak etanol daun sirsak dapat memicu kejadian apoptosis pada KIII, KIV, KV sebesar 2,5\%, 3,44\%, dan 3,56\% lebih tinggi dari kejadian apoptosis kelompok kontrol positif sebesar $1,80 \%(p<0,05)$. Dapat disimpulkan ekstrak etanol daun sirsak berpotensi memiliki efek kemoterapi pada kanker payudara tikus putih yang diinduksi DMBA.
\end{abstract}

Kata Kunci: Ekstrak daun sirsak, efek kemoterapi, DMBA, kanker payudara

\section{ABSTRACT}

Breast cancer is the most common cancer suffered in women and needs high cost chemotherapy which also has so many side effects. Leaves of the soursop (Annona muricata) contain acetogenin which is cytotoxic against the cancer cells. This study aims to determine the chemotherapy effects of soursop leaves to breast cancer of white rats. This research was conducted in the experimental laboratory of anatomical pathology of medical faculty in Lampung University from May to September 2013 by using 25 female Sprague Dawley rats divided into 5 groups, namely group I as negative control, group II was given $75 \mathrm{mg} / \mathrm{kg}$ DMBA, group III was given $75 \mathrm{mg} / \mathrm{kg} D M B A+$ extract of soursop leaves $100 \mathrm{mg} / \mathrm{kg}, \mathrm{group} \mathrm{III,75mg/kg}$ $D M B A+$ extract of soursop leaves $200 \mathrm{mg} / \mathrm{kg}, 75 \mathrm{mg} / \mathrm{kg} B B D M B A+111400 \mathrm{mg} / \mathrm{kg}$ BW extract of soursop leaves. The soursop leave extracts were administered for 4 weeks. Histopathology examination was performed to assess apoptosis after administration of soursop leaves. The results were analyzed using Kruskall Wallis test and Man Whitney test. Soursop leave ethanol extract can cause apoptosis in KIII, KIV, KV by 2,5\%, 3,44\%, and 3,56\% higher than the apoptosis of positive control group by $1,80 \%(p<0,05)$. In conclusion, the ethanol extract of soursop leaves has potential effect of chemotherapy in breast cancer in DMBA induced white rats.

Keywords: Breast cancer, chemotherapy effect, DMBA, ethanol extract of soursop leaves

Jurnal Kedokteran Brawijaya, Vol. 28, No. 2, Agustus 2014; Korespondensi: Muhartono. Bagian Patologi Anatomi Fakultas Kedokteran Universitas Lampung Bandar Lampung, Jl. Prof. Dr. Sumantri Brojonegoro No. 1 Bandar Lampung, 35145 Tel. (721) 701609 Email: dmuhartono@yahoo.com 


\section{PENDAHULUAN}

Kanker payudara merupakan salah satu jenis kanker yang sering ditemukan pada wanita. Sebanyak $20 \%$ dari seluruh kasus keganasan di dunia adalah kanker payudara. Insiden kanker payudara di Amerika Serikat mencapai 232.670 kasus dan angka mortalitas 62.570. Insiden kanker payudara di Indonesia sebanyak 8.227 kasus atau sebesar $16,85 \%$ dan angka mortalitas mencapai $50 \%$ pada tahun 2007. Diperkirakan insiden tersebut semakin bertambah dari tahun ke tahun $(1,2)$.

Pengobatan terhadap kanker payudara dapat dilakukan melalui operasi, radiasi atau dengan memberikan kemoterapi. Pengobatan kemoterapi seringkali didapatkan efek samping seperti kerontokan rambut, rasa mual yang luar biasa, dan sakit kepala (3). Hingga saat ini belum ditemukan pengobatan yang ideal untuk menyembuhkan kanker (2).

Indonesia memiliki banyak tumbuhan yang dianggap memiliki zat anti kanker. Salah satu tumbuhan yang banyak digunakan adalah sirsak (Annona muricata). Sirsak digunakan untuk mengobati kanker dengan cara meminum rebusan daunnya $(2,4)$. Daun sirsak mengandung asetogenin yang memiliki aktifitas anti kanker (5).

Mekanisme sitotosik dari asetogenin daun sirsak masih belum jelas. Diduga asetogenin dapat menginhibisi sistem transpor elektron dan oksidasi Nicotinamida Adenosin Dinukleotida Hidrogen (NADH) dari metabolisme sel kanker. Asetogenin merupakan inhibitor kuat dari kompleks I mitokondria atau NADH dehidrogenase yang dapat mengakibatkan penurunan produksi Adenosin Triposphat (ATP) $(6,7)$.

\section{METODE}

Penelitian ini dilaksanakan di laboratorium Patologi Anatomi Fakultas Kedokteran Universitas Lampung pada 1 Mei-10 September 2013. Penelitian ini merupakan penelitian eksperimental dengan post test-only control group design dengan menggunakan 25 ekor tikus putih (Rattus norvegicus) galur Sprague Dawley betina berusia 5 minggu, dipilih secara acak dan dibagi dalam 5 kelompok. Kelompok I (KI), merupakan kelompok kontrol yaitu kelompok yang tidak diberi 7.12-Dimetilbenz(a)Antrasen (DMBA) dan hanya diberi aquadest; Kelompok II diberi DMBA $75 \mathrm{mg} / \mathrm{kg}$ BB sebagai bahan penginduksi kanker payudara pada tikus putih dan aquadest; Kelompok III diberi DMBA $75 \mathrm{mg} / \mathrm{kg}$ BB dan $100 \mathrm{mg} / \mathrm{kg}$ BB ekstrak etanol daun sirsak; Kelompok IV diberi DMBA $75 \mathrm{mg} / \mathrm{kg}$ BB dan $200 \mathrm{mg} / \mathrm{kgBB}$ ekstrak etanol daun sirsak, Kelompok V, diberi DMBA $75 \mathrm{mg} / \mathrm{kg}$ BB dan 400mg/kgBB ekstrak etanol daun sirsak selama 4 minggu.

Adanya apoptosis diketahui melalui pengamatan mikroskopis pada pewarnaan Hematoxilin-Eosin. Pemeriksaan dilakukan menggunakan mikroskop dengan perbesaran 100 kali. Sel yang mengalami apoptosis dihitung dalam 200 sel tumor di setiap lapang pandang dan pemeriksaan dilakukan pada 5 lapang pandang yang berbeda (1000 sel tumor). Perhitungan sel apoptosis dilakukan secara duplo oleh peneliti yang sama pada waktu yang berbeda, kemudian kedua hasil pembacaan diambil reratanya. Indeks Apoptosis (AI) dihitung sebagai prosentasi apoptosis sel dibagi jumlah seluruh sel tumor (8).

Analisa data menggunakan SPSS 21.0, uji Shapiro-wilk digunakan untuk uji normalitas data dan uji homogenitas data menggunakan uji Levene. Pembuktian hipotesa dilakukan dengan uji Kruskal Wallis yang merupakan uji alternatif dari uji One Way ANOVA dilanjutkan dengan uji post hoc Mann Whitney. Uji statistik dilakukan pada derajat kepercayaan $95 \%$ dengan $\alpha=0,05$. Hasil uji dinyatakan bermakna bila $\mathrm{p}<0,05$.

\section{HASIL}

Hasil uji Shapiro-wilk menunjukan bahwa data berdistribusi normal ( $p>0,05)$ namun, uji homogenitas data menunjukan data memiliki varians yang tidak homogen $(p=0,007)$, sehingga pembuktian hipotesis dilakukan menggunakan uji Kruskal Wallis. Data hasil penelitian dengan uji Kruskal Wallis menunjukan adanya perbedaan indeks apoptosis yang signifikan antara kelompok kontrol positif dengan paling tidak satu kelompok perlakuan yang ditunjukan dengan nilai $p=0,034$.

Pemberian ekstrak ethanol daun sirsak dengan berbagai konsentrasi menunjukan adanya perbedaan pada indeks apoptosis. Rerata indeks apoptosis kelompok tikus yang diberi DMBA $75 \mathrm{mg} / \mathrm{kg}$ BB tanpa diberi ekstrak ethanol daun sirsak (kontrol positif) menunjukan nilai paling rendah $(1,8 \pm 0,19)$ lalu meningkat secara berurutan, seiring dengan meningkatnya dosis pemberian ekstrak etanol daun sirsak pada kelompok perlakuan, yaitu 2,54 $\pm 0,42$ pada kelompok dengan dosis terkecil $(100 \mathrm{mg} / \mathrm{kg} \mathrm{BB})$, $3,44 \pm 1,24$ pada kelompok dosis kedua $(200 \mathrm{mg} / \mathrm{kg} \mathrm{BB})$ dan yang tertinggi $3,56 \pm 1,16$ pada dosis terbesar $(400 \mathrm{mg} / \mathrm{kg}$ $\mathrm{BB})$.

Hasil uji Mann Whitney dalam uji post hoct yang dilakukan menunjukan adanya perbedaan yang signifikan $(p<0,05)$ antara kelompok kontrol positif dengan kelompok perlakuan III (dosis $100 \mathrm{mg} / \mathrm{kg} \mathrm{BB}$ ) dan V (dosis $400 \mathrm{mg} / \mathrm{kg}$ BB) $(p=0,016$ dan $p=0,016)$. Ini menandakan bahwa pemberian ekstrak etanol daun sirsal secara peroral dengan dosis 100 dan $400 \mathrm{mg} / \mathrm{kg}$ BB dapat menginduksi proses apoptosis pada sel tumor payudara tikus putih yang diinduksi DMBA. Antara kelompok kontrol positif dan kelompok perlakuan IV (dosis $200 \mathrm{mg} / \mathrm{kg}$ BB) tidak menunjukan adanya perbedaan yang signifikan $(p=0,115)$ yang dapat diartikan pemberian ekstrak ethanol daun sirsak sebesar $200 \mathrm{mg} / \mathrm{kg}$ BB belum mampu menginduksi apoptosis pada sel tumor payudara tikus putih yang diinduksi DMBA meskipun secara angka terdapat perbedaan diantara keduanya. Indeks apoptosis pada kelompok kontrol positif $=1,8 \pm 0,19$ dan pada kelompok $\mathrm{IV}=3,44 \pm 1,24$.

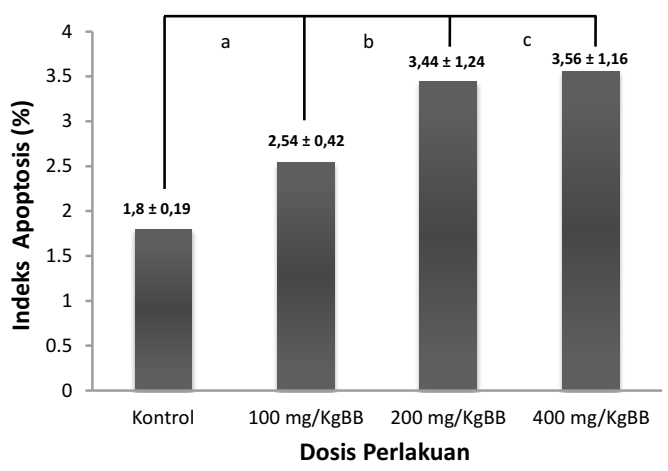

Gambar 1. Grafik nilai mean \pm standar deviasi indeks apoptosis setelah pemberian ekstrak etanol daun sirsak Keterangan:

a. Signifikan antara kontrol positif dengan kelompok III $(p=0,016)$

b. Tidak signifikan antara kontrol positif dengan kelompok IV $(p=0,115)$

c. Signifikan antara kontrol positif dengan kelompok $V(p=0,016)$ 


\section{DISKUSI}

Daun sirsak telah lama dipercaya oleh sebagian masyarakat sebagai obat kanker. Daun sirsak diketahui memiliki beberapa senyawa aktif seperti asetogenin, flavonoid, saponin dan alkaloid $(9,10)$. Studi in vitro sebelumnya menunjukan bahwa daun sirsak memiliki aktivitas anti kanker terhadap kultur sel kanker payudara T47D (11). Berdasarkan fakta tersebut maka ekstrak daun sirsak diperkirakan dapat memiliki aktivitas anti kanker secara in vivo.

Hasil penelitian menunjukan bahwa pemberian ekstrak etanol daun sirsak secara peroral mampu memicu kematian sel melalui mekanisme apoptosis yang ditunjukan dengan adanya perbedaan indeks apoptosis yang signifikan antara kelompok kontrol positif dengan kelompok perlakuan $(p<0,05)$. Hal ini sesuai dengan beberapa penelitian sebelumnya yang menyatakan bahwa senyawa aktif daun sirsak dapat menyebabkan apoptosis sel kanker (12-14).

Mekanisme apoptosis ekstrak daun sirsak diperkirakan melalui penghambatan glucose transpoter (GLUT) pada membran plasma. Penghambatan GLUT mengakibatkan kebutuhan glukosa sel kanker tidak tercukupi, sehingga merangsang timbulnya apoptosis (13). Ekstrak daun sirsak diduga mampu menghambat kompleks I mitokondria yang berperan dalam respirasi penyediaan energi pada sel sehingga dapat menyebabkan apotosis melalui jalur mitokondria (15).

Mekanisme lainnya terkait apoptosis, diperkirakan

\section{DAFTAR PUSTAKA}

1. Baskaran N, Manoharan S, Balakrishnan S, and Pugalendhi P. Chemopreventive Potential of Ferulic Acid in 7,12-dimethylbenz[a]anthracene-Induced Mammary Carcinogenesis in Sprague-Dawley Rats. Eropean Journal of Pharmacology. 2010; 637(1-3): 22-29.

2. Retnani V dan Prajoko YW. Pengaruh Suplementasi Ekstrak Daun Annona muricata terhadap Kejadian Displasia Epitel Kelenjar Payudara Tikus Spraque d a w l e y y a n g Di ind uksi 7, 12 Dimethylbenz[a]anthracene. [Skripsi]. Universitas Diponegoro, Semarang. 2011.

3. Kurnijasanti R, Hamid IS, dan Rahmawati K. Efek Sitotoksik In Vitro Ekstrak Buah Mahkota Dewa (Phaleria Macrocarpa) terhadap Kultur Sel Kanker Mieloma. Jurnal Penelitian Medika Eksakta. 2008; $7(1): 48-54$

4. Wijaya M. Ekstraksi Annonaceous Acetogenin dari Daun Sirsak, Annona Muricata, sebagai Senyawa Bioaktif Anti Kanker. [Skripsi]. Universitas Indonesia, Jakarta. 2012.

5. de Sousa OV, Vieira GD, de Jesus R G de Pinho J, Yamamoto $\mathrm{CH}$, and Alves MS. Antinociceptive and Anti-Inflammatory Activities of The Ethanol Extract of Annona Muricata L. Leaves in Animal Models. International Journal of Molecular Science. 2010; 11(5): 2067-2078.

6. Mclaughin JL, Benson GB and Forsyth JW. A Novel Mechanism for the Control of Clinical Cancer: Inhibition of the Production of Adenosine ekstrak daun sirsak menghambat NADH pada enzim uniquinone oxidoreductase. Enzim ini merupakan enzim esensial dalam sistem transpor elektron yang digunakan untuk fosforilasi oksidatif di dalam mitokondria. Hal ini mengakibatkan gradien proton antar membran yang diciptakan oleh kompleks I selama reduksi NADH oleh ubiquinone dan transfer elektron yang memungkinkan untuk reduksi pernafasan dari $\mathrm{O} 2$ ke $\mathrm{H} 2 \mathrm{O}$ dihambat, sehingga mengurangi level ATP secara signifikan (16).

Penurunan kadar ATP secara signifikan ini menyebabkan sel tumor menjadi kekurangan energi yang sangat dibutuhkan oleh sel untuk berproliferasi. Kondisi ini dapat menyebabkan dimulainya proses apoptosis. Penurunan $\mathrm{Bcl}-2$ maupun $\mathrm{Bcl}-\mathrm{x}$ akan menyebabkan peningkatan permeabilitas membran mitokondria yang menyebabkan keluarnya sitokrom c. Sitokrom c yang berada di sitosol membentuk kompleks dengan Apaf-1 dan kompleks caspase 9 aktif. Kompleks ini merupakan protease yang bertugas memotong atau mendegradasi protein lain. Salah satunya adalah procaspase 3 menjadi caspase 3 (17).

Caspase 3 merupakan kelompok dari cysteine aspartic acid protease yang berperan sebagai caspase eksekutor. Peningkatan caspase 3 yang telah diaktifkan akan memotong sitoskleton sel dan matrik protein nukleus. Sel yang sudah terpotong-potong ini dinamakan apoptotic bodies, yang selanjutnya akan dikenali oleh makrofag untuk di fagositosis (17). Berdasarkan hasil penelitian ini dapat disimpulkan bahwa ekstrak etanol daun sirsak berpotensi memiliki efek kemoterapi pada kanker payudara tikus putih yang diinduksi DMBA.

Triphosphate (ATP) With a Standardized Extract of Paw Paw (Asimincz Triloba, Anonaceae). (Online) 2003. http://www.pawpawresearch.com/pawpawtrials1.pdf [diakses tanggal diunduh 1 April 2013].

7. Gonzalez CA, Guadano A, de Ines C, Martinez DR, and Cortes D. Selective Action of Acetogenin Mithocondrial Complex I Inhibitors. Zeitschrift für Naturforschung C. 2002; 57(11-12): 1028-1034.

8. Rahmawati E, Dewoto HR, and Wuyung PE. Anticancer Activity Study of Ethanol Extract of Mahkota Dewa Fruit Pulp (Phaleria Macrocarpa (Scheff.) Boerl.) in C3H Mouse Mammary Tumor Induced by Transplantation. Medical Journal of Indonesia. 2006; 15(4): 217-222.

9. Liaw CC, Chang FR, Chen SL, Wu CC, Lee KH, and Wu YC. Novel Cytotoxic Monotetrahydrofuranic Annonaceous Acetogenins from Annona Montana. Bioorganic \& Medicinal Chemistry. 2005; 13(15): 4767-4776.

10. Formagio AS, Vieira Mdo C, Dos Santos LA, et al. Composition and Evaluation of the Anti-Inflammatory and Anticancer Activities of the Essential Oil from Annona sylvatica A. St.-Hil. Journal of Medicinal Food. 2013; 16(1): 20-25.

11. Rachmani EPN, Suhesti TS, Widiastuti R, dan Aditiyono. The Breast of Anticancer from Leaf Extract of Annona Muricata Against Cell Line in T47D. International Journal of Applied Science and Technology. 2012; 2(1): 157-164.

12. Matsui Y, Takefumi T, Kumamoto-Yonezawa Y, et al. The Relationship between the Molecular Structure of Natural Acetogenins and Their Inhibitory Activities which Affect DNA Polymerase, DNA Topoisomerase 
and Human Cancer Cell Growth (Review). Experimental and Theraupetic Medicine. 2010; 1(1): 19-26.

13. Cerella C, Radogna F, Dicato $M$, and Diedrich $M$. Natural Compounds as Regulators of the Cancer Cell Metabolism. International Journal of Cell Biology. 2013; 2013: 1-16.

14. Ren W, Qiao Z, Wang H, Zhu L, and Zhang L. Flavonoids: Promising Anticancer Agents. Medicinal Research
Reviews. 2003; 23(4): 519-534.

15. Gorman JST. Transition Metal-mediated Cyclizations and Synthesis of Annonaceous Acetogenin Analogs. [Repository]. University of Texas, Texas. 2006.

16. Villo P. Synthesis of Acetogenin Analogues. [Thesis]. University of Tartu, Estonia. 2008.

17. Kumar V, Abbas AK, and Fausto N. Pathologic Basic of Disease. 7th edition. Philadelphia: Elsevier Saunders; 2004. 